\title{
A Research About the Cultural Influences of America to Shanghai Since 1972
}

\author{
ZHANG Sheng \\ Shanghai Academy of Social Sciences, Shanghai, China
}

\begin{abstract}
The city of Shanghai was for a long time known as the Paris of the Orient, and sometimes as New York West. In 1972, the United States of America and the People’s Republic of China Published the Shanghai Joint Communique. Since then, the America culture had great influences to Shanghai, from TV series to fast food, sports, and tourism, and so on.
\end{abstract}

Keywords: Shanghai, America, cultural influences

\section{Introduction: Nixon's Visit in China and the Shanghai Joint Communique}

On 21 February 1972, a U.S. aircraft landed at the Shanghai Hongqiao International Airport. U.S. President Richard Nixon, together with his wife and a retinue, was on board Air Force One of America. They would be proceeding to Peking after a short transit at the airport. U.S. Secretary of State William Rogers and National Security Adviser Dr. Henry Kissinger were among the president’s entourage.

Shanghai had always treated American guests accompanying U.S. presidents on official visits with utmost respect, particularly first-time visitors to China via Shanghai. There was a certain mystique about the Chinese land, which made the guests nervous and constrained.

As the host, Shanghai would give due consideration to the needs of these Americans and make arrangements for all the activities in accordance to their wishes and requests.

Quality service was provided by Jin Jiang Hotel in terms of accommodation needs as well as various commercial and service units. It took less than 20 minutes to complete the immigration procedure for every batch of American guests who disembarked in Shanghai.

In the morning of 27 February, the 278-member contingent, including President Nixon, left Hangchow and arrived in Shanghai for a one-day visit. They were accompanied by Chinese Premier Zhou Enlai, Acting Chinese Foreign Minister Ji Pengfei, Vice Chinese Foreign Minister Qiao Guanhua, and others. Nixon and his wife were invited to tour the Shanghai Industrial Exhibition with Zhou. Despite the fine weather, there was still a nip in the air in early spring. Upon entering the exhibition hall, Zhou had his overcoat removed and looked exceptionally spirited. Nixon followed suit and commented, "I want to make it known that I am as warm-blooded as the Premier”. The U.S. president admired the heavy industry and technology exhibits with great interest and stopped to listen from time to time as he was being guided through the exhibits. During a demonstration of how to operate an open double-column cold extrusion press, he lent a hand by pressing the start button. When the processed item was taken out, Zhou said to Nixon with a smile, "You have just made a 
constructive push", to which the latter gladly replied, "Yes, yes, it is indeed constructive".

This was certainly a monumental day in the history of Sino-U.S. relations. After a week of talks and negotiations between leaders of China and America, the Joint Communique of the United States of America and the People's Republic of China (also known as the Shanghai Communique) was eventually reached and issued by both parties in Shanghai.

The issue of the Shanghai Communique signified the commencement of t he normalization of bilateral relations between China and the U.S., and served as the basis of improvement and development in future Sino-American ties. Later, in his address at a reception dinner held by the Shanghai Municipal Revolutionary Committee that evening, Nixon shared by saying, "This was the week that changed the world, as what we have said in that Communique is not really as important as what we will do in the years ahead to build a bridge across 16,000 miles and 22 years of hostilities which have divided us in the past”.

\section{American Television Series and Shanghai}

American television series have been long associated with Shanghai and China. Towards the end of 1980, following the airing of Garrison's Gorillas on Chinese television, pet names of its characters, such as "Head", "Actor", and "Chief”, became widely known across China. Kids loved to mimic the roles of these characters in all seriousness, for example, they would use a folding knife meant for sharpening pencils as the switchblade of "Chief" and dart it at the doors of neighbors.

However, the ABC production had not been well-received by American audience, and was only premiered in China after a long lapse of 13 years since its debut in the U.S. Thereafter, the successive airing of a series of U.S. television dramas in China, including the likes of My Favorite Martian by CBS, Growing Pains by ABC, and Hunter by NBC, had been an eye-opener to many Chinese families. Yet, for a long time, Chinese audience could only watch U.S. television series through state-owned television stations, which were known for their slow response to market trends. It was not until mid-1990s that the situation finally saw a change, owing to the policy of reform and opening-up in coastal regions of China. Around 1995, television audience in the coastal region of Guangdong had the opportunity of watching the original English version of Friends with the help of Chinese subtitles through Hong Kong's TVB Pearl. They were the pioneer batch of Chinese audience to watch the television serial.

Then, around 2000, with growing prevalence of DVD playback devices in China, as well as the introduction of classic television series in DVD format by various American television networks, the horizon of Chinese audience became enriched at an unexpected rate, since television shows on DVD were not subject to censorship. Friends, which was considered the first American television drama to be known by DVD fanatics in China, attracted the notice of customers through the recommendation of DVD shop owners of foresight. In spite of doubts before watching the sitcom, they were so pleasantly surprised by it that they encouraged their relatives and friends to catch it as well. Following widespread publicity in the form of public praise, China saw the first wave of upsurge in U.S. television series in the new century. Now, it is common to see American television drama fans buying and watching DVDs.

From The West Wing by NBC to HBO's Band of Brothers, people have gradually established a connection with the American television world via DVDs. Fox Network's 24 and Prison Break, which were winner and nominee of Primetime Emmy Awards respectively, had enjoyed great popularity in China. Wentworth Miller, the male lead in Prison Break, a U.S. television drama, had been warmly addressed as "mi shuai" (the 
handsome Miller) by Chinese fans of American television series. It was perhaps beyond his imagination that he would become so popular in China or even Shanghai. The ME \& CITY brand under Metersbonwe invited Miller to be its brand ambassador, and had a billboard several times his size put up on Nanjing Road, which was testimony of his popularity in Shanghai.

\section{American Fast Food and Shanghai}

Fast food culture, which is largely symbolic in the framework of quintessential American way of life, has transcended regional, country and racial cultural differences as well as dietary barriers. It has openly conquered the world in the form of a popular lifestyle and culture mode.

Originally a family business, Kentucky Fried Chicken (KFC) was said to be associated with an American colonel who succeeded late in life. It is not only a popular fast food chain in Europe and the U.S. but also in large and medium cities of Asia and particularly China, Shanghai included. The image of a healthy and kind-looking elderly man in front of all franchise KFC stores has become an icon of western fast food and is known to all in China. On the other hand, McDonald's, an international top brand, has taken the world by storm with its driving development tendency. Its main target consumers are youths, nearly all of whom have eaten at a McDonalds in Shanghai.

American fast food is well characterized by high efficiency, convenience, and hygiene. Besides embodying the values and objective needs of Americans, it is also the most widely identified and accepted modern F\&B consumption concept globally, and has swept across the world with great momentum. The greatest impact of American fast food on Shanghai and China as a whole is the innovation and development of Chinese fast food, such as Yonghe Soy Milk and Daniang Dumpling. Since Chinese cuisine relies on traditional cooking techniques which emphasize the coordination of color, aroma, flavor, presentation, and shape, the flow of fast food has acted contrary to the essence of Chinese culinary art. Yet, under the influence of American fast food, Chinese snacks have surprisingly become a hit as well. The familiar pagoda mark of Chinese fast food is often highlighted in American movies or television dramas, whereby blond Americans are seen wolfing down fried dumplings and fried rice. We cannot help but chuckle, for it seems that Chinese and western cultures can be easily fused into one.

\section{Yao and NBA}

It has been eight years long since Yao retired from NBA Rockets. But the big man is still a symbol of Chinese players to American people.

Following the entry of Yao Ming, a lanky Shanghai-born basketball player into NBA, Americans have become increasingly drawn to the Chinese culture. Meanwhile, American basketball culture as typified by NBA has also taken root in China, particularly Shanghai.

Houston Rockets players, be it big names or nobodies, have attracted innumerable Chinese fans overnight, a clear demonstration of the "Yao Ming effect". Role players, originally unknown in the basketball field, are the ones who have directly benefited from the "Yao Ming effect".

As described on the NBA official website, how much is Yao Ming really worth? The answer is obvious by simply looking at those who are related to him, without the need of going through the trouble of estimating his huge paycheck. 
Ever since Yao Ming had been recruited by Houston Rockets, his teammates had also become advertising celebrities hotly sought after by sponsors, majority of which were Chinese enterprises. Notable Chinese sports manufacturers had signed endorsement contracts with the likes of Steve Francis, Luis Scola, Shane Battier, Ron Artest, and Dikembe Mutombo. China brand sneakers could be seen everywhere in the Rockets' changing room, while large billboards of Chinese enterprises were strategically displayed on its home ground.

Yao Ming, who hails from Shanghai, has become the signature of the city worldwide.

Shanghai has launched a short film to promote its city image under the ambassadorship of Yao. Based on the theme of "Magic Shanghai, Magic Yao", the film was shot on location at iconic landscapes of the city, for example, Shanghai Pudong International Airport, Shanghai Exhibition Center, Lujiazui Green Land, Pudong Riverside (Binjiang) Avenue, etc. The extraordinary spirit of common people from all walks of life in Shanghai came through in the humorous plot as Yao made his appearance in various scenes and trades, thereby portraying a brand new city image of Shanghai.

\section{New Landmark: Shanghai Disney Resort}

As the forerunner of American animation films, Walt Disney had been known for his imaginative power and creative spirit. In 1955, he set up the first modern amusement park in California. Named Disneyland (or the official full name of Disneyland Park), it was not only the earliest of its kind to be built, but the world's pioneer theme park in modern sense as well. Fictional cartoon characters like Mickey Mouse were being transformed into realistic images in the 64.7-hectare theme park lying $35 \mathrm{~km}$ from Los Angeles. Visitors to the theme park, where life-size cartoon images could be found, were kept entertained with various activities, such as steering the future car, taking a ride on the Mississippi stern car, having fun in the tower house, or strolling along the Main Street, USA. So far, apart from the Disneyland in Los Angeles, California, there are also theme parks in other parts of the world, including Walt Disney World Resort (Orlando), Tokyo Disneyland, Disneyland Paris, Hong Kong Disneyland, Tokyo Disney Sea, and so on.

China, with its dense population and potential spending power, has attracted interest from The Walt Disney Productions of the U.S. in establishing a theme park in Shanghai. The Shanghai Disney Resort opened in 2016. It located in Chuansha of Pudong New District. Like Hong Kong Disneyland, Shanghai Resort is a new landmark of Shanghai. And it has become a land to come for all visitors from all over China.

\section{References}

Del Deo, A., \& Stern, J. D. (2004). The years of the Yao/endgame entertainment. NBA entertainment. United States: Fine Line Features.

Huskey, J. L. (2014). Americans in Shanghai. Shanghai: Shanghai Chishu Publishing House.

Tao, W. Z. (2004). A history of China and the America. Shanghai: Shanghai Renmin Publishing House.

Xiong, Y. Z. (1999). Shanghai general history. Shanghai: Shanghai Renmin Publishing House. 